\title{
Analisis Kualitas Pelayanan Bus Samsat Keliling Unit Pelayanan Pendapatan Daerah Medan Selatan Badan Pengelolaan Pajak Dan Retribusi Daerah Provinsi Sumatera Utara
}

\section{Analysis of the Service Quality of Mobile Samsat Bus Regional Revenue Service Unit South Medan Regional Tax and Levy Management Agency North Sumatra Province}

\author{
Hubalillah1), Badaruddin'2) \& Heri Kusmanto2)* \\ 1)Program Studi Magister Ilmu Administrasi Publik, Program Pascasarjana, \\ Universitas Medan Area, Indonesia \\ 2)Departemen Ilmu Politik, Fakultas Ilmu Sosial dan Ilmu Politik, \\ Universitas Sumatera Utara Area, Indonesia
}

Diterima: 13 Agustus 2021; Direview: 13 Agustus 2021; Disetujui: 29 Desember 2021

\begin{abstract}
Abstrak
Tujuan adari artikel ini adalah untuk menganalisis pelayanan dan faktor-faktor penghambat pelayanan Bus Samsat keliling Unit Pelayanan Pendapatan Daerah (UPPD) Medan Selatan Badan Pengelolaan Pajak Dan Retribusi Daerah Provinsi Sumatera Utara (BPPRDSU). Penelitian ini menggunakan metode deskriptif dengan teknik analisis kualitatif. Dengan teknik pengumpulan data dari wawancara, dokumentasi, dan observasi. Berdasarkan hasil wawancara dan observasi yang menggunakan 4 indikator dari Tjiptono (2002) mengenai kualitas pelayanan Bus Samsat Keliling di Simpang Pemda Kecamatan Medan Selayang, sudah baik atau berkualitas. Namun kenyamanan masih kurang baik atau kurang memadai di karenakan sarana yang masih terbatas. Hambatan yang sering ditemukan adalah masyarakat yang mengeluh terhadap fasilitas. Di karenakan sarana yang ada masih kurang memuaskan. Kemudian tidak disiplinnya Petugas Bus Samsat Keliling di Simpang Pemda Kecamatan Medan Selayang. Yaitu Petugas Bus Samsat Keliling Simpang Pemda Kecamatan Medan Selayang masuk dan pulang kantor tidak tepat waktu. Serta masyarakat menginginkan waktu pengoperasian Bus Samsat Keliling Simpang Pemda Kecamatan Medan Selayang dapat di perpanjang.

Kata Kunci: Analisis; Bus Keliling; Kualitas Pelayanan; Unit Pelayanan Pendapatan Daerah; Badan Pengelolaan
\end{abstract} Pajak Dan Retribusi Daerah.

\section{Abstrak}

The purpose of this article is to analyze the service and the inhibiting factors of the Samsat Bus service around the Regional Revenue Service Unit (UPPD) of South Medan BPPRDSU. This study uses a descriptive method with qualitative analysis techniques. With data collection techniques from interviews, documentation, and observation. Based on the results of interviews and observations using 4 indicators from Tjiptono (2002) regarding the service quality of the Mobile Samsat Bus at Simpang Pemda Medan Selayang District, it is good or quality. However, comfort is still not good or inadequate because the facilities are still limited. Barriers that are often found are people who complain about the facilities. This is because the existing facilities are still unsatisfactory. Then the undisciplined officers of the Mobile Samsat Bus at the Simpang Pemda Medan Selayang District. Namely, the Samsat Bus Officers at the Simpang Simpang Pemda Medan Selayang Subdistrict enter and leave the office on time. And the community wants the operation time of the Samsat Roving Bus at the Medan Selayang District Government to be extended.

Keywords: Analysis; Round Trip Bus; Service quality; Regional Revenue Service Unit; Regional Tax and Levy Management Agency.

How to Cite: Hubalillah. H., Badaruddin, B., \& Kusmanto, H. (2022). Analisis Kualitas Pelayanan Bus Samsat Keliling Unit Pelayanan Pendapatan Daerah Medan Selatan Badan Pengelolaan Pajak Dan Retribusi Daerah Provinsi Sumatera Utara. PERSPEKTIF, 11 (1): 372- 384.

*Corresponding author:

E-mail: herikusmanto@usu.ac.id 


\section{PENDAHULUAN}

Pelayanan publik pada prinsipnya adalah tuntutan yang lahir dari masyarakat, agar masyarakat mendapatkan hak dan perlakuan yang layak dari Negara dalam beraktivitas dan mempertahankan keberadaannya sebagai warga Negara. Untuk itu pelayanan publik yang diberikan oleh Negara harus berorientasi pada kepentingan publik. Pemenuhan terhadap kepentingan publik ini secara sesungguhnya memperhatikan kualitas layanan yang diberikan, agar masyarakat yang dilayani dapat memberikan respon positif terhadap hasil layanan yang diberikan. Goetsh dan Davis dalam Arif (2006) menterjemahkan kualitas merupakan suatu kondisi dinamis yang berhubungan dengan produk, jasa, manusia, proses, dan lingkungan yang memenuhi atau melebihi harapan. Bahwa kualitas memiliki keterkaitan erat dengan upaya untuk memenuhi kebutuhan manusia yang tidak saja menyangkut produk dan jasa semata, tetapi juga menyentuh pada aspek proses dan lingkungan.

Menurut Sampara (2000) mendefinisikan pelayanan sebagai kegiatan atau urutan kegiatan yang terjadi dalam interaksi langsung antara seseorang dengan orang lain secara fisik dan menyediakan kepuasan pelanggan. Berdasarkan pendapat di atas bahwa produk layanan yang diberikan oleh penyedia layanan tidak saja membutuhkan interaksi secara langsung, tetapi juga harus mampu menyediakan pelayanan yang dapat memuaskan masyarakat. Suatu pelayanan dapat dikatakan berkualitas, manakala produk pelayanan yang dihasilkan dapat memberikan manfaat bagi pelanggan (masyarakat yang dilayani). Tujuan kualitas pelayanan adalah memberikan dampak terhadap pemenuhan kebutuhan masyarakat (pengguna layanan). Dengan kata lain, tingginya kualitas pelayanan tidak hanya dapat dicermati dari proses pelayanan yang berlandaskan pada prosedur dan peraturan, tetapi yang jauh lebih penting adalah bagaimana produk layanan yang dihasilkan dapat memberikan kepuasan terhadap masyarakat yang dilayani (Narita et al., 2016; Hendrawan et al., 2018; Ningrum et al., 2019; Khainuddin et al., 2019).

Pelayanan publik merupakan suatu bentuk layanan yang diberikan birokrasi atau pemerintah kepada masyarakat. Pelaksanaan pelayanan publik dimaksudkan untuk memenuhi kebutuhan-kebutuhan yang sesuai dengan keinginan dan harapan masyarakat. Karena pada hakikatnya pemerintah merupakan abdi masyarakat atau public servant. Sesuai dengan Undang-Undang No. 25 Tahun 2009, pelayanan publik diartikan sebagai kegiatan atau rangkaian kegiatan dalam upaya memenuhi kebutuhan pelayanan yang sesuai dengan peraturan perundangundangan bagi setiap warga negara atas barang dan jasa, maupun pelayanan administratif yang disediakan oleh penyelenggara pelayanan publik. Pelayanan publik merupakan upaya pemerintah untuk memenuhi kebutuhan masyarakat. Pelayanan yang diberikan kepada masyarakat harus senantiasa baik dan berkualitas mendekati harapan masyarakat karena baik buruknya pelayanan publik yang diberikan birokrat kepada masyarakat sering dijadikan tolak ukur keberhasilan suatu instansi pemerintah (Silalahiet al., 2019; Panjaitan et al., 2019; Minallah et al., 2021; Prasetio et al., 2021; Saputra et al., 2021)

Samsat Unit Pelayanan Pendapatan Daerah (UPPD) Medan Selatan Badan Pengelolaan Pajak Dan Retribusi Daerah Provinsi Sumatera Utara (BPPRDSU), merupakan salah satu instansi yang bertugas memberikan pelayanan publik berupa jasa secara langsung kepada masyarakat. Pelayanan di Samsat UPPD Medan Selatan BPPRDSU meliputi berbagai macam pelayanan atau pengurusan pajak kendaraan bermotor. Salah satunya Bus Samsat Keliling. Pengertian Samsat keliling adalah pelayanan pengesahan pembayaran Pajak Kendaraan Bermotor untuk setiap tahunnya yang berada di pinggir jalan pusat kota dan berpindah-pindah yang memiliki kemudahan-kemudahan yang tidak dapat dijumpai di Kantor Samsat. Samsat dapat diibaratkan sebagai suatu cabang birokrasi yang berada di tengah-tengah birokrasi dan masyarakat. Untuk dapat mengetahui kegiatan dan gambaran pelayanan Bus Samsat Keliling UPPD Medan Selatan, dapat di lihat pada Tabel 1. 
Hubalillah, Badaruddin \& Heri Kusmanto, Analisis Junedi Lumban Gaol, Muryanto Amin \& Heri Kusmanto. Demokratisasi Dan Desentralisasi Partai Demokrasi Indonesia Perjuangan

Tabel 1. Kegiatan Pelayanan Bus Samsat Keliling UPPD Medan Selatan BPPRDSU

\begin{tabular}{llll}
\hline No. & Hari & Tempat & Jumlah WP \\
\hline \multirow{3}{*}{ Bus Samkel 1} & Senin & Patumbak & 35 \\
\cline { 2 - 4 } & Selasa & Tj. Anom & 30 \\
\cline { 2 - 4 } & Rabu & Carrefour P. Bulan & 45 \\
\cline { 2 - 4 } & Kamis & Bromo & 40 \\
\cline { 2 - 4 } & Jum'at & Johor & 35 \\
\cline { 2 - 4 } & Sabtu & Carrefour P. Bulan & 45 \\
\hline \multirow{3}{*}{ Bus Samkel 2} & Senin & Namorambe & 45 \\
\cline { 2 - 4 } & Selasa & Denai & 65 \\
\cline { 2 - 4 } & Rabu & Star Ban Polonia & 45 \\
\cline { 2 - 4 } & Kamis & Wahidin & 60 \\
\cline { 2 - 4 } & Jum'at & Timpang Pemda Selayang & 90 \\
\cline { 2 - 4 } & Sabtu & Tejo/Setiabudi & 80 \\
\hline
\end{tabular}

Sumber: Data Unit Pelayanan Pendapatan Daerah (UPPD) Medan Selatan Badan Pengelolaan Pajak Dan Retribusi Daerah Provinsi Sumatera Utara, 2020.

Pada posisinya di masyarakat, Bus Samsat Keliling UPPD Medan Selatan BPPRDSU harus memberikan pelayanan yang memuaskan kepada masyarakat sebagai pengguna layanan baik pelayanan barang maupun pelayanan jasa. Maka, Bus Samsat Keliling UPPD Medan Selatan BPPRDSU berkewajiban untuk memberikan pelayanan yang optimal.

Wibawa (2005) menjelaskan bahwa terdapat beberapa alasan Samsat UPPD Medan Selatan BPPRDSU harus memberi pelayanan yang optimal yaitu, wajib pajak memiliki hak untuk dihormati. Wajib pajak bukan bawahan instansi yang dapat diperintah paksa. Pelayanan jasa yang dilakukan di Samsat UPPD Medan Selatan BPPRDS memang tidak berwujud seperti pelayanan barang. Subarsono (Dwiyanto, 2008) menjelaskan bahwa meskipun wujud pelayanan tidak nampak, proses penyelenggaraannya dapat diamati dan dapat dirasakan, misal apakah layanan yang dilakukan dapat dinilai cepat, lambat, menyenangkan, menyulitkan, murah atau mahal. Bus Samsat Keliling UPPD Medan Selatan BPPRDS sebagai salah satu birokrasi pemerintah yang memberikan pelayanan kepada masyarakat juga tidak luput dari berbagai permasalahan terkait penyelenggaraan pelayanan publik.

Fenomena permasalahan yang sering terjadi di Bus Samsat Keliling UPPD Medan Selatan BPPRDS antara lain tuntutan masyarakat atas perbaikan pelayanan dalam hal kelengkapan kendaraan baik yang bersifat fisik maupun administrasi yang mudah dan cepat dikarenakan mobilitas masyarakat yang semakin tinggi dalam berlalu lintas. Selain itu permasalahan waktu pelayanan kerja Bus Samsat Keliling UPPD Medan Selatan BPPRDS yang bersamaan dengan waktu kerja masyarakat. Seringkali masyarakat harus meninggalkan aktivitasnya atau meminta izin tidak masuk agar dapat melakukan pembayaran. Bila pelayanan yang diberikan tidak tepat waktu maka masyarakat harus meluangkan waktu lebih banyak untuk mengurus. Sebanyak 2 unit Bus Samsat Keliling dioperasikan BPPRDSU sampai dengan Tahun 2019, untuk semakin mendekatkan pelayanan kepada masyarakat wajib pajak.

Namun, peneliti melihat bahwa masih ada keluhan masyarakat dalam pemberian pelayanan. Hal ini dikarenakan tidak digunakannya nomor urut antrian pelayanan di Bus Samsat Keliling Unit Pelayanan Pendapatan Daerah (UPPD) Medan Selatan Badan Pengelolaan Pajak Dan Retribusi Daerah Provinsi Sumatera Utara (BPPRDSU). Selanjutnya terkait penyelenggaraan pelayanan di Bus Samsat keliling UPPD Medan Selatan BPPRDS juga belum maksimal dalam fasilitas.

Permasalahan lain yaitu maraknya praktik percaloan. Praktik percaloan yang masih sering ditemui di berbagai birokrasi penyelenggaraan pelayanan publik tidak terkecuali di Bus Samsat Keliling UPPD Medan 
Selatan BPPRDS. Peneliti berpendapat masih ditemukan banyak calo yang berkeliaran di sekitar tempat parkir untuk menawarkan jasanya kepada wajib pajak yang akan mengakses pelayanan. Banyaknya calo yang berkeliaran di sekitar tentu memprihatinkan dan meresahkan masyarakat. Calo sering memaksa masyarakat yang datang untuk menggunakan jasanya. Padahal ini sangat merugikan masyarakat karena bila menggunakan jasa calo masyarakat harus mengeluarkan biaya lebih tinggi. Meskipun begitu, pada kenyataannya masih ada masyarakat yang menggunakan jasa calo. Hal tersebut sejalan dengan pernyataan Wibawa (2005) bahwa ada juga masyarakat yang ingin serba cepat dan instan lalu menggunakan jasa calo karena tidak ingin berurusan dengan prosedur yang dianggapnya rumit.

Untuk dapat meningkatkan kualitas pelayanan dan untuk memecahkan permasalahan yang sering terjadi di organisasi publik, maka dibutuhkan suatu penyelesaian agar pelayanan dapat menjadi lebih baik. Selain itu Bus Samsat Keliling UPPD Medan Selatan BPPRD yang dilakukan dengan kendaraan bus yang didesain menyerupai kantor akan memudahkan masyarakat dalam membayar. Dengan prosedur yang tidak berbelit dan lokasi yang dapat dijangkau karena berada di keramaian, diharapkan masyarakat tidak punya alasan lagi untuk tidak membayar.

Pada hakikatnya kantor bersama Samsat sebagai kantor pelayanan terkait dengan administrasi kendaraan bermotor di bidang perpajakan daerah yang di kenal SAMSAT. Dalam aktifitasnya kepada masyarakat oleh 4 instansi sesuai tugas pokoknya yaitu BPPRDSU, DITLANTAS, Bank SUMUT sebagai tempat loket pembayaran dan PT. JASA RAHARJA. Pelayanan Bus Samsat Keliling UPPD Medan Selatan BPPRDS bertujuan untuk memberikan kepuasan masyarakat sebagai pengguna pelayanan. Samsat UPPD Medan Selatan BPPRDS sebagai salah satu instansi pemerintah daerah harus mampu melayani masyarakat secara maksimal dari penyelenggaraan pelayanan, kinerja aparat, dan mekanisme kerja yang ada. Selain itu kepuasan masyarakat sebagai wajib pajak merupakan hal yang sangat penting untuk diperhatikan aparat pajak. Wajib Pajak dalam membayar pajaknya tidak merasakan imbalan secara langsung, maka wajar bila dalam proses pemungutan pajak diimbangin dengan kualitas pelayanan yang baik.

Berdasarkan uraian di atas peneliti tertarik untuk meneliti lebih dalam mengenai kualitas pelayanan Bus Samsat keliling UPPD Medan Selatan BPPRDSU yang di fokuskan hanya kepada 1 Bus Samsat Keliling yang berada di Simpang Pemda Kecamatan Medan Selayang dalam melaksanakan tugas pokok dan menjalankan fungsinya sebagai pelaksana operasional di Kota Medan dalam mewujudkan kualitas pelayanan yang optimal. Maka dalam hal ini peneliti tertarik untuk menganalisis bagaimana kualitas pelayanan Bus Samsat Keliling Simpang Pemda Kecamatan Medan Selayang.

Tabel 2. Penelitian Terdahulu

\begin{tabular}{|c|c|c|}
\hline Nama & Judul & Hasil \\
\hline $\begin{array}{l}\text { Skripsi. Faisal riza. Jurusan } \\
\text { Ilmu Administrasi. Fakultas } \\
\text { Ilmu Sosial Dan Ilmu } \\
\text { Politik. Universitas Sebelas } \\
\text { Maret. Surakarta. 20o9. }\end{array}$ & \begin{tabular}{|lr} 
Kualitas & Pelayanan \\
Kantor & Samsat \\
Surakarta. & \\
\end{tabular} & $\begin{array}{l}\text { Kualitas pelayanan SAMSAT } \\
\text { dikatakan belum memenuhi harapan } \\
\text { masyarakat sebagai wajib pajak. Untuk } \\
\text { fasilitas pelayanan masih perlu dibenahi, } \\
\text { seperti tempat parkir yang kurang } \\
\text { memenuhi harapan wajib pajak. } \\
\text { Kehandalan pegawai SAMSAT dalam } \\
\text { memberikan pelayanan kepada wajib } \\
\text { pajakkurang memuaskan, hal ini nampak } \\
\text { pada pelayanan kepada wajib pajak. Pada } \\
\text { pelayanan yang diberikan kepada wajib } \\
\text { pajak yangmengurusi BBNKB kurang } \\
\text { memuaskan karena beberapa pegawai } \\
\text { memberikan informasi yang berbelit-belit. } \\
\text { Pegawai SAMSAT juga belum memberikan } \\
\text { tanggapan yang memuaskan bagi wajib } \\
\text { pajak. Untuk memberikan informasi, }\end{array}$ \\
\hline
\end{tabular}


Hubalillah, Badaruddin \& Heri Kusmanto, Analisis Junedi Lumban Gaol, Muryanto Amin \& Heri Kusmanto. Demokratisasi Dan Desentralisasi Partai Demokrasi Indonesia Perjuangan

\begin{tabular}{|c|c|c|}
\hline & & $\begin{array}{l}\text { pegawai SAMSAT sudah cukup baik, } \\
\text { tetapimasih perlu ditingkatkan lagi untuk } \\
\text { masalah koordinasi antar petugas. }\end{array}$ \\
\hline Nama & Judul & Hasil \\
\hline $\begin{array}{l}\text { Jurnal Perpajakan.Leli } \\
\text { Ardiani, Kadarisman } \\
\text { Hidayat, Sri Sulasmiyati. PS } \\
\text { Perpajakan, Jurusan Ilmu } \\
\text { Administrasiranisnis, } \\
\text { Fakultas Ilmu Administrasi, } \\
\text { Universitas Brawijaya. 2016. }\end{array}$ & $\begin{array}{l}\text { Implementasi Layanan } \\
\text { Inovasi Samsat Keliling } \\
\text { Dalam Upaya } \\
\text { Meningkatkan } \\
\text { Pelayanan Pembayaran } \\
\text { Pajak Kendaraan } \\
\text { Bermotor (Studi Pada } \\
\text { Kantor Bersama Samsat } \\
\text { Kabupaten } \\
\text { Tulungagung). }\end{array}$ & $\begin{array}{l}\text { Terdapat beberapa kemudahan dalam } \\
\text { layanan inovasi SAMSAT Keliling. } \\
\text { Kemudahan } \begin{array}{l}\text { tersebut } \\
\text { penyederhanaan persyaratan pelayanan, }\end{array} \\
\text { penyederhanaan prosedur pelayanan serta } \\
\text { peningkatan waktu pelayanan. Mayoritas } \\
\text { Wajib Pajak merasa puas akan adanya } \\
\text { layanan inovasi SAMSAT Keliling, karena } \\
\text { layanan inovasi SAMSAT Keliling dianggap } \\
\text { sangat membantu dan memudahkan Wajib } \\
\text { Pajak. }\end{array}$ \\
\hline Nama & Judul & Hasil \\
\hline $\begin{array}{lrr}\text { Jurnal } & \text { SAWALA. } & \text { Ari } \\
\text { Ramdani, } & \text { STIA } & \text { YPPT } \\
\text { Priatim, } & \text { Tasikmalaya. } & 2018 .\end{array}$ & $\begin{array}{lr}\text { Penerapan } & \text { Inovasi } \\
\text { Pelayanan } & \text { Publik } \\
\text { Samsat Keliling } & \text { Di Kota } \\
\text { Tasikmalaya. } & \end{array}$ & $\begin{array}{l}\text { Berdasarkan hasil penelitian dan uraian } \\
\text { pembahasan, maka dapat disimpulkan } \\
\text { bahwa Penerapan Inovasi Pelayanan Publik } \\
\text { SAMSAT Keliling Di Kota Tasikmalaya } \\
\text { dapat di katakan berjalan dengan baik, } \\
\text { karena } 3 \text { kriteria dari karakteristik Inovasi } \\
\text { Pelayanan Publik. } \\
\text { 1. Ada tidaknya dampak positif atau } \\
\text { kemanfaatan dari suatu inisiatif perubahan. } \\
\text { 2. Mampu memberi solusi terhadap } \\
\text { masalah. } \\
\text { 3. Inovasi haruslah berkesinambungan, dan } \\
\text { sudah diterapkan dalam pemberian } \\
\text { pelayanan berupa layanan pengesahan } \\
\text { STNK setiap tahun, pembayaran PKB dan } \\
\text { SWDKLLJ kepada masyarakat. }\end{array}$ \\
\hline Nama & Judul & Hasil \\
\hline $\begin{array}{lr}\text { Jurnal } & \text { Tesis. } \\
\text { Resmityowati, } & \text { Maria } \\
\text { Rosaria, } & \text { Universitas } \\
\text { Brawijaya. 2016. } & \end{array}$ & $\begin{array}{l}\text { Efektivitas Layanan } \\
\text { SAMSAT Keliling } \\
\text { Dalam Upaya } \\
\text { Meningkatkan } \\
\text { Kepatuhan Wajib } \\
\text { Pajak Kendaraan } \\
\text { Bermotor. Survei } \\
\text { Pada Wajib Pajak } \\
\text { Pengguna Layanan } \\
\text { Sistem Administrasi } \\
\text { Manunggal Satu Atap } \\
\text { (SAMSAT) Keliling. }\end{array}$ & $\begin{array}{l}\text { Efektivitas pelaksanaan pelayanan } \\
\text { Pembayaran Pajak Kendaraan Bermotor di } \\
\text { SAMSAT Keliling Malang Utara dan Batu } \\
\text { Kota Tahun } 2011 \text { termasuk ke dalam kriteria } \\
\text { kurang efektif. Tahun } 2012 \text { termasuk ke } \\
\text { dalam kriteria efektif. Tahun } 2013 \text { hingga } \\
\text { Tahun } 2015 \text { termasuk ke dalam kriteria } \\
\text { sangat efektif. Faktor-faktor yang menjadi } \\
\text { pendukung dalam pelaksanaan pelayanan } \\
\text { pembayaran Pajak Kendaraan Bermotor di } \\
\text { SAMSAT Keliling Malang Utara dan Batu } \\
\text { Kota yaitu adanya lokasi yang strategis } \\
\text { untuk didirikannya SAMSAT Keliling, } \\
\text { petugas yang ramah dan pelayanan yang } \\
\text { cepat, serta terpenuhinya sistem IT yang } \\
\text { memadahi, yang digunakan untuk } \\
\text { memasukkan semua data Wajib Pajak. } \\
\text { Faktor-faktor yang menghambat dalam } \\
\text { pelayanan pembayaran Pajak Kendaraan } \\
\text { Bermotor di SAMSAT Keliling Kabupaten } \\
\text { Malang Utara dan Batu Kota yaitu antrian }\end{array}$ \\
\hline
\end{tabular}




\begin{tabular}{|l|l|l|}
\hline & & $\begin{array}{l}\text { yang kurang disiplin dan fasilitas antrian } \\
\text { yang kurang memadahi. }\end{array}$ \\
\hline
\end{tabular}

Sumber: Hasil kajian peneliti, 2020.

\section{METODE PENELITIAN}

Dalam penelitian ini peneliti menggunakan pendekatan kualitatif. Peneliti menggunakan kualitatif karena pendekatan kualitatif memiliki ruang yang sempit namun memiliki bahasan yang lebih mendalam dibandingkan dengan penelitian kuantitatif. Seperti yang dikemukakan oleh Muhadjir (dalam Aman, 2007) bahwa penelitian kualitatif merupakan penelitian yang lebih mengutamakan pada masalah proses dan makna atau persepsi, di mana penelitian ini diharapkan dapat mengungkap berbagai informasi kualitatif dengan deskripsi-analisis yang teliti dan penuh makna. Berdasarkan teori di atas, peneliti menggunakan bahwa pendekatan kualitatif dalam penelitian ini dianggap tepat karena sejalan dengan judul penelitian yang diambil sehingga tidak dituangkan dalam bentuk bilangan dan angka statistik. Melaui pendekatan tersebut, peneliti berharap bisa memperoleh gambaran dari pernasalahan yang terjadi secara mendalam.

Subjek penelitian adalah orang yang diminta untuk memberikan keterangan tentang suatu fakta atau pendapat. Sebagaimana dijelaskan oleh Arikunto (2013) subjek penelitian adalah subjek yang dituju untuk diteliti. Maka subjek penelitian itu merupakan sumber informasi yang digali untuk mengungkapkan fakta-fakta di lapangan. Berdasarkan penjelasan tersebut, maka penentuan subjek penelitian digunakan untuk memperoleh informasi yang akan dibutuhkan secara jelas dan mendalam. Informan adalah orang-orang yang dimanfaatkan untuk memberikan informasi tentang situasi dan latar belakang penelitian. Adapun yang menjadi informan dalam penelitian ini sebagai berikut:

Informan telah lama terlibat dengan satu kegiatan yang menjadi sasaran perhatian peneliti yaitu Wajib Pajak yang sedang melakukan pembayaran pajak di Bus Samsat Keliling Simpang Pemda Kecamatan Medan Selayang.

Informan yang masih terkait secara penuh dan aktif pada lingkungan atau kegiatan yang menjadi sasaran yaitu Petugas Bus
Samsat Keliling Simpang Pemda Kecamatan Medan Selayang.

Informan yang mempunyai cukup informasi, banyak waktu dan kesempatan untuk diminta keterangan terkait masalah penelitian yaitu Polri, karyawan PT. Jasa Raharja dan karyawan Bank SUMUT. Teknik pengumpulan data merupakan langkah yang paling strategis dalam penelitian, karena tujuan utama dari penelitian ini adalah mendapatkan data. Adapun teknik yang digunakan oleh peneliti untuk mengumpulkan dari penelitian ini adalah sebagai berikut:

Pelaksanaan observasi dilakukan pada saat penelitian berlangsung di lokasi penelitian. Yang diamati dalam penelitian ini yaitu aktivitas petugas Bus Samsat Keliling Simpang Pemda Kecamatan Medan Selayang dan aktivitas wajib pajak selama proses pembayaran pajak berlangsung. Dalam hal ini peneliti langsung turun ke lapangan untuk mengamati perilaku dan aktivitas individuindividu di lokasi penelitian. Dalam penelitian ini, peneliti mencatat baik mengenai pelayanan yang di berikan petugas Bus Samsat Keliling Simpang Pemda Kecamatan Medan Selayang kepada wajib pajak terhadap pelaksanaan adanya program Bus Samsat Keliling tersebut. Dalam penelitian ini peneliti datang ke lokasi penelitian tanpa ikut terlibat dalam kegiatan tersebut atau tidak mengikuti kegiatan yang dilakukan oleh informan penelitian. Disini peneliti hanya mengamati, menanyakan dan mendengar segala hal yang terjadi kemudian menuliskan data-data yang dapat mendukung penelitian.

Pelaksanaan wawancara adalah teknik pengumpulan data dengan cara berdialog dan berdiskusi antara dua pihak yaitu peneliti dengan informan mengenai permasalahanpermasalahan yang dibahas dalam penelitian ini yang bertujuan untuk mengumpulkan data mengenai pelayanan para petugas Bus Samsat Keliling Simpang Pemda Kecamatan Medan Selayang terhadap wajib pajak dan bagaimana pelaksanaan program dengan adanya Bus Samsat Keliling dalam memudahkan segala urusan masyarakat dalam pembayaran pajak.

Menurut Suyanto (2005) dokumentasi dalam pengumpulan data penelitian 
Hubalillah, Badaruddin \& Heri Kusmanto, Analisis Junedi Lumban Gaol, Muryanto Amin \& Heri Kusmanto. Demokratisasi Dan Desentralisasi Partai Demokrasi Indonesia Perjuangan

dimaksudkan sebagai cara mengumpulkan data dengan mempelajari dan mencatat bagianbagian yang dianggap penting dan berbagai dokumen resmi yang dianggap baik dan ada pengaruhnya dengan lokasi penelitian. Dokumentasi yang diambil oleh peneliti berupa laporan kegiatan saat peneliti berada di Bus Samsat Keliling Simpang Pemda Kecamatan Medan Selayang, dokumentasi gambar kegiatan pelaksanaan pembayaran pajak oleh wajib pajak, dokumentasi data-data dari BPPRDSU berupa profil BPPRDSU dan UPPD Samsat Medan Selatan.

Miles dan Huberman dalam (Sugiyono, 2007) mengemukakan bahwa aktivitas dalam analisis data kualitatif dilakukan secara interaktif dan berlangsung terus menerus sampai tuntas, hingga datanya jenuh. Aktivitas tersebut adalah reduksi data (data reduction), penyajian data (data display), dan conclusion drawing/verification. Dapat disimpulkan bahwa teknik analisis data kualitatif dilakukan secara langsung oleh peneliti dan pengumpulan data dilakukan secara terus menerus sampai menemukan titik jenuh atau menemukan hasil yang diinginkan. Dan dengan melalui 3 tahap aktivitas. Yang diantaranya adalah:

Data Reduction (Reduksi Data). Setelah data dari lapangan terkumpul dan di analisis maka tahap selanjutnya adalah pengkategorian data untuk dibuat reduksinya, sehingga akan diperoleh data yang paling dapat memberikan gambaran lebih jelas. Menurut Sugiyono (2010) mereduksi data berarti merangkum, memilih hal-hal yang pokok memfokuskan pada hal-hal penting dicari tema dan polanya. Reduksi data bertujuan untuk mempermudah pemahaman terhadap data yang telah dikumpulkan dari hasil penelitian dilapangan. Data yang diperoleh dari lapangan ditulis dalam uraian yang terinci, kemudian uraian tersebut dirangkum, dipilih hal-hal yang pokok, difokuskan pada hal-hal yang penting sesuai dengan rumusan masalah yang berkaitan dengan pelayanan Bus Samsat Keliling Simpang Pemda Kecamatan Medan Selayang. Dalam hal ini data yang telah direduksi akan memberikan gambaran yang lebih jelas, dan mempermudah penelitian untuk melakukan penelitian dan untuk melakukan pengumpulan data selanjutnya, dan mencarinya bila diperlukan.

Data Display (Penyajian Data). Penyajian ini dapat memberikan gambaran hasil penelitian secara terperinci dan menyeluruh sesuai dengan pola hubungannya. Penyajian data merupakan hasil wawancara dengan Wajib Pajak, Petugas Bus Samsat Keliling Simpang Pemda Kecamatan Medan Selayang, Polri, karyawan PT. Jasa Raharja dan karyawan Bank SUMUT. Sementara itu observasi lapangan berisikan hasil pengamatan peneliti selama berada dilapangan. Kemudian ada pula studi dokumentasi yang berisikan data-data yang berhubungan dengan penelitian. Keseluruhan data tersebut dipahami secara terpisah, kemudian disatukan dan di interpretasikan sesuai dengan rumusan masalah.

\section{Conclusion Drawing/Verification.}

Langkah ketiga dalam analisis data kualitatif adalah penarikan kesimpulan dan verifikasi. Menurut Sugiyono (2010) mengemukakan bahwa kesimpulan dalam penelitian kualitatif mungkin dapat menjawab rumusan masalah yang dirumuskan sejak awal. Kesimpulan data verifikasi dalam penelitian ini yakni mendapat hasil dari penelitian yang dilaksanakan dalam bentuk pertanyaan singkat dan mudah dipahami sehingga menyimpulkan mengenai gambaran mengenai pelayanan Bus Samsat Keliling Simpang Pemda Kecamatan Medan Selayang.

\section{HASIL DAN PEMBAHASAN \\ Analisis Kualitas Pelayanan Bus Samsat Keliling Di Simpang Pemda Kecamatan Medan Selayang}

Adanya pelayanan Bus Samsat Keliling adalah untuk meningkatkan kepatuhan wajib pajak. Dengan adanya Bus Samsat Keliling agar meningkatkan kualitas pelayanan dengan memberikan kemudahan kepada wajib pajak dalam melakukan pembayaran. Pelayanan Bus Samsat Keliling tidak hanya melayani pajak kendaraan bermotor namun informasi mengenai hal-hal layanan perpajakan. Pelayanan dengan menggunakan bus ini dapat mengakses masyarakat yang berada di wilayah yang sangat jauh dari akses perkotaan. Dengan adanya pelayanan menggunakan layanan bus ini, akan memberikan dampak positif bagi kesadaran masyarakat dalam hal membayar pajak. Masyarakat akan semakin patuh melakukan pembayaran di karenakan adanya kemudahan dalam prosedur pembayaran dan kecepatan serta ketetapan juga kemudahan 
pelayanan yang di berikan petugas. Kepatuhan dalam membayar juga dilakukan untuk terkenanya denda atas keterlambatan pembayaran yang melewati jatuh tempo. Jadwal pelayanan Bus Samsat Keliling ini dapat di laksanakan dengan jadwal sosialisasi yang sudah di siapkan dan di informasikan terlebih dahulu kepada masyarakat.

Untuk menganalisis bagaimana kualitas pelayanan Bus Samsat Keliling yang di sediakan oleh UPPD Medan Selatan BPPRDSU, maka peneliti lebih memfokuskan untuk menganalisis bagaimana kualitas pelayanan Bus Samsat Keliling yang berada di Simpang Pemda Kecamatan Medan Selayang.

Kecepatan. Kecepatan petugas Bus Samsat Keliling Simpang Pemda Kecamatan Medan Selayang pada saat pelayanan untuk kebutuhan masyarakat sangatlah penting. Dengan begitu kecepatan saat pelayanan akan terjalin dua arah antara Samsat dengan masyarakat sebagai wajib pajak. Selain adanya kordinasi antara beberapa instansi terkait, juga diperlukan komunikasi dengan masyarakat atau wajib pajak untuk mengetahui baik buruknya pelayanan yang telah diberikan. Salah satu upaya Samsat Keliling Simpang Pemda Kecamatan Medan Selayang untuk memberikan informasi terkait adanya program Bus Samsat Keliling adalah dengan melakukan sosialisasi. Sosialisasi kepada masyarakat di lakukan melalui media cetak, elektronik maupun jejaring sosial.

Berdasarkan hasil observasi yang peneliti lihat di lokasi, bahwa dalam rangka memberikan pelayanan kepada masyarakat, Bus Samsat Keliling Simpang Pemda Kecamatan Medan Selayang juga mempersilahkan pengguna layanan untuk menyampaikan kritik, saran dan masukan kepada Samsat UPPD Medan Selatan BPPRDSU atas pelayanan yang diberikan. Samsat UPPD Medan Selatan BPPRDSU menyediakan opsi pengaduan bagi masyarakat yang ingin menyampaikan saran atau masukan maupun kritiknya.

Selain dari media pengaduan untuk mengetahui tanggapan dari wajib pajak atas pelayanan yang diberikan, maka peneliti melakukan wawancara dengan beberapa wajib pajak yang sedang melakukan pengurusan di Bus Samsat Keliling Simpang Pemda Kecamatan Medan Selayang.
Adanya program Bus Samsat Keliling UPPD Medan Selatan dari BPPRDSU selain memberikan dampak bagi Samsat dan Jasa Raharja, juga memberikan dampak bagi masyarakat sebagai wajib pajak yang langsung merasakan hasilnya dari program ini. Dalam pelayanan Bus Samsat Keliling Simpang Pemda Kecamatan Medan Selayang sudah memberikan prosedur yang tidak berbelit-belit dan persyaratannya jelas. Dengan begitu dapat memudahkan wajib pajak dalam membayar pajak kendaraan. Prosedur pelayanan merupakan langkah yang harus dilalui atau mekanisme dalam menggunakan pelayanan, tidak terkecuali pelayanan pada Bus Samsat Keliling Simpang Pemda Kecamatan Medan Selayang. Dengan begitu pelayanan pembayaran pajak kendaraan yang di tujukan untuk memudahkan masyarakat lebih sederhana di bandingkan dengan pelayanan melalui Kantor Samsat Induk.

Kecepatan dalam memberi pelayanan yang cepat dan tepat merupakan bagian dari kualitas pelayanan. Mengartikan bahwa petugas harus dapat memberikan pelayanan yang cepat dan tanggap. Hal ini juga sesuai dengan Keputusan Badan Pengelolaan Pajak Dan Retribusi Daerah Provinsi Sumatera Utara Tentang Standard Operasional Prosedur (SOP) Di Lingkungan Badan Pengelolaan Pajak Dan Retribusi Daerah Provinsi Sumatera Utara Unit Pelaksana Teknis Pengelolaan Dan Pendapatan Daerah Tahun 2019. Cara kerja petugas Bus Samsat Keliling Simpang Pemda Kecamatan Medan Selayang dalam melayani masyarakat sudah baik atau berkualitas. Hasil penelitian ini mendukung penelitian sebelumnya yang dilakukan Resmityowati, Maria Rosaria, Universitas Brawijaya (2016) dengan judul Efektivitas Layanan SAMSAT Keliling Dalam Upaya Meningkatkan Kepatuhan Wajib Pajak Kendaraan Bermotor. Survei pada wajib pajak pengguna layanan Sistem Administrasi Manunggal Satu Atap (SAMSAT) Keliling. Yang menyimpulkan bahwa petugas pelayanan pembayaran Pajak Kendaraan Bermotor di SAMSAT Keliling Malang Utara dan Batu Kota terlihat ramah serta pelayanan yang cepat, dan terpenuhinya sistem IT yang memadahi, yang digunakan untuk memasukkan semua data wajib pajak. Hal ini sesuai dengan hasil wawancara dan observasi yang peneliti lakukan terlihat bahwa petugas Bus Samsat Keliling Simpang Pemda Kecamatan Medan 
Hubalillah, Badaruddin \& Heri Kusmanto, Analisis Junedi Lumban Gaol, Muryanto Amin \& Heri Kusmanto. Demokratisasi Dan Desentralisasi Partai Demokrasi Indonesia Perjuangan

Selayang dapat berbaur kepada wajib pajak. Hal itu terlihat saat wajib pajak masih bingung dalam pembayaran maka petugas akan memberikan arahan benar dengan responsiv atau cepat.

Ketepatan. Pelayanan Bus Samsat Keliling Simpang Pemda Kecamatan Medan Selayang di laksanakan dalam enam hari kerja setiap minggunya yaitu dari hari Senin sampai dengan hari Sabtu sesuai dengan waktu operasional Bus Samsat Keliling Simpang Pemda Kecamatan Medan Selayang. Pelayanan Bus Samsat Keliling Simpang Pemda Kecamatan Medan Selayang tidak dapat melakukan registrasi dan cek fisik kendaraan bermotor. Di karenakan Bus Samsat Keliling Simpang Pemda Kecamatan Medan Selayang hanya bisa melakukan untuk teliti ulang atau pengesahan pajak tahunan. Untuk di hari Jum'at Bus Samsat Keliling Simpang Pemda Kecamatan Medan Selayang hanya sampai jam 12.00 siang setelah itu tidak dapat melakukan pembayaran lagi.

Apabila program Bus Samsat Keliling Simpang Pemda Kecamatan Medan Selayang di kelola dengan baik tentunya akan menarik masyarakat untuk memudahkan membayar pajak dan tidak lagi mengandalkan calo dengan alasan antri lama, sibuk bekerja, atau tidak paham cara bayarnya. Selain itu adanya program Bus Samsat Keliling Simpang Pemda Kecamatan Medan Selayang juga dapat diakses kapanpun dan dimanapun dengan harapan tidak mengganggu rutinitas wajib pajak yang mayoritas bekerja dan tidak memiliki banyak waktu jika harus mengantri lama di Samsat Induk.

Waktu pelayanan sangat berpengaruh terhadap wajib pajak, karena tidak semua wajib pajak memiliki banyak waktu, banyak pekerjaan yang tidak bisa ditinggalkan seperti pegawai kantor, guru, pedagang. Maka dengan adanya keluhan masyarakat, Samsat memiliki upaya dengan menciptakan program Bus Samsat Keliling untuk meningkatkan pelayanan pembayaran pajak. Dengan memberikan pelayanan kepada masyarakat agar masyarakat merasakan adanya kepuasan, maka salah satu hal penting dan mendasar yang harus di perhatikan yaitu adanya ketepatan durasi waktu penyelesaian pelayanan.

Dari hasil wawancara dan hasil observasi dapat di katakan bahwa ketepatan waktu pada Bus Samsat Keliling Simpang Pemda
Kecamatan Medan Selayang sudah baik atau berkualitas. Hal tersebut terlihat dari banyaknya informan yang menyatakan puas dengan ketepatan waktu penyelesaian layanan tersebut. Dari hasil wawancara hanya satu orang informan yang menyatakan bahwa ketepatan waktu penyelesaian akan bergantung dengan jumlah masyarakat yang antri. Jika masyarakat sedikit yang berurusan, kemungkinan akan tepat waktu. Namun jika masyarakat banyak yang akan berurusan, kemungkinan bisa memakan waktu. Hasil penelitian ini juga sesuai dengan penelitian terdahulu yang di lakukan oleh Leli Ardiani, Kadarisman Hidayat, Sri Sulasmiyati. PS Perpajakan, Jurusan Ilmu Administrasi Bisnis, Fakultas Ilmu Administrasi, Universitas Brawijaya (2016) dengan judul Implementasi Layanan Inovasi Samsat Keliling Dalam Upaya Meningkatkan Pelayanan Pembayaran Pajak Kendaraan Bermotor (Studi Pada Kantor Bersama Samsat Kabupaten Tulungagung). Yang menunjukkan bahwa dalam pelayanan pajak kendaraan bermotor di SAMSAT Kota Yogyakarta dapat dinilai efisien jika masyarakat memperoleh pelayanan dalam waktu singkat dan tidak banyak membutuhkan banyak tenaga.

Keramahan. Selain ketepatan waktu, wajib pajak juga mengharapkan keramahan yang baik dari petugasnya. Berdasarkan hasil observasi, peneliti juga melihat bagaimana sikap petugas dalam memberikan pelayanan kepada wajib pajak yang terlihat ramah dan selalu memberikan bantuan kepada wajib pajak atau masyarakat ketika mengalami kesulitan dalam pembayaran pajak dan memberikan informasi-informasi tentang pelayanan. Dengan adanya program Bus Samsat Keliling merupakan suatu sistem kerja sama yang terdiri dari 4 instansi yaitu Ditlantas Poldasu, BPPRDSU, PT. Jasa Raharja dan Bank SUMUT. Maka, jika para petugas tidak menjalin kerja sama yang baik terhadap masyarakat dengan menciptakan pelayanan yang baik, peneliti berpendapat tidak akan dapat berjalan dengan semestinya.

Oleh karena itu dalam melaksanakan pelayanan tersebut keempat instansi haruslah melakukan koordinasi yang baik agar tercipta pelayanan yang baik juga. Petugas Bus Samsat Keliling harus berusaha menjalin pelayanan dengan baik kepada masyarakat sebagai wajib 
pajak. Di karenakan sikap petugas dalam memberikan pelayanan merupakan menjadi perhatian khusus dalam setiap penyelenggaraan pelayanan publik. Sikap petugas yang ramah tentunya akan memberikan kenyamanan bagi pengunjung. Sesuai dengan observasi, peneliti melihat bahwa petugas berusaha semaksimal mungkin untuk memberikan pelayanan yang baik. Dapat dikatakan bahwa kemampuan petugas dalam memberikan pelayanan kepada masyarakat cukup mampu dalam menjalankan tugasnya sebagai pelayan masyarakat. Dan peneliti juga melihat para petugas sudah mempunyai pengalaman yang cukup dalam bidangnya.

Dari hasil wawancara dan hasil observasi peneliti saat berada di Bus Samsat Keliling Simpang Pemda Kecamatan Medan Selayang, terlihat petugas menyapa para wajib pajak dengan ramah dan sopan sebelum melakukan pelayanan, serta memberikan informasiinformasi terkait prosedur dan persyaratan apa saja yang harus wajib pajak siapkan. Selanjutnya dari hasil tersebut di kaitkan dengan teori Kasmir (dalam Pasolong 2013) yang mengatakan bahwa pelayanan yang baik adalah kemampuan seseorang dalam memberikan pelayanan yang dapat memberikan kepuasan kepada pelanggan dengan standar yang ditentukan. Kesimpulan yang peneliti dapatkan bahwa keramahan pelayanan petugas pada Bus Samsat Keliling Simpang Pemda Kecamatan Medan Selayang sudah baik atau berkualitas, di buktikan dengan sikap petugas dalam memberikan pelayanan kepada wajib pajak terlihat sopan dan selalu memberikan bantuan kepada wajib pajak ketika mengalami kesulitan dan memberikan informasi-informasi.

Kenyamanan. Di tinjau dari segi kenyamanan yang ada, terdapat masyarakat yang mengeluh terhadap pelayanan Bus Samsat Keliling Simpang Pemda Kecamatan Medan Selayang. Dari hasil observasi peneliti Bus Samsat Keliling Simpang Pemda Kecamatan Medan Selayang, dari segi sarana dalam pelayanan sangatlah kurang. Seperti lingkungan yang panas karena berdekatan dengan simpang lampu merah dan saat wajib pajak sedang mengantri tidak di sediakan tempat duduk untuk menunggu. Dengan adanya hal seperti ini maka masyarakat akan merasa kurang puas dalam pelayanan.
Pelayanan yang terdapat pada Bus Samsat Keliling ini sifatnya hanya sementara. Di karenakan tujuan utama adanya program Bus Samsat Keliling ini hanya untuk orang-orang yang jauh dari Kantor Samsat Induk. Dan dapat mengurangi biaya perjalanan. Peneliti menyimpulkan bahwa sarana sangatlah berperan penting dan berpengaruh dalam pelayanan. Padahal, jika wajib pajak merasa puas dengan adanya program Bus Samsat Keliling ini, maka masyarakat akan patuh dalam membayar pajak yang akan terus meningkat. Berdasarkan hasil observasi, peneliti juga melihat tidak adanya sistem nomor urut antrian. Dan ini menjadikan masyarakat yang diberi pelayanan harus menunggu panggilan dari pengeras suara. Sehingga wajib pajak harus benar-benar mendengarkan panggilan yang ada.

Di dalam pelayanan, kenyamanan bagi wajib pajak dan kelancaran petugas dalam memberikan pelayanan sangatlah penting. Kenyamanan dapat berdampak langsung terhadap kepuasan wajib pajak karena dapat dirasakan langsung oleh pengguna layanan. Berdasarkan hasil wawancara dan observasi peneliti, kenyamanan untuk wajib pajak tidak di rasakan sama sekali sehingga kenyamanan di nilai tidak berkualitas atau kurang baik. Di karenakan kurangnya sarana yang ada di lokasi. Seperti tempat parkir yang terbatas, kursi bagi wajib pajak yang tidak ada, tidak adanya nomor urut antrian, tidak ada tenda, sehingga seringkali merasa kepanasan dan kehujanan di saat cuaca tidak mendukung. Hasil penelitian tersebut memiliki relevansi dengan penelitian sebelumnya yang di lakukan Faisal Riza, Jurusan Ilmu Administrasi, Fakultas Ilmu Sosial Dan Ilmu Politik, Universitas Sebelas Maret, Surakarta (2009) yang berjudul Kualitas Pelayanan Kantor Samsat Surakarta. Yang menyatakan bahwa kualitas pelayanan Samsat dapat dikatakan belum memenuhi harapan masyarakat sebagai wajib pajak. Untuk fasilitas pelayanan masih perlu di benahi, seperti tempat parkir yang kurang memenuhi harapan wajib pajak.

Berdasarkan hasil penelitian yang menggunakan 4 indikator dari Tjiptono (2002) mengenai kualitas pelayanan pada Bus Samsat Keliling Simpang Pemda Kecamatan Medan Selayang, maka hasil yang di dapat sudah berkualitas. Petugas sudah melakukan pelayanan dengan baik dan berkualitas, hal itu 
Hubalillah, Badaruddin \& Heri Kusmanto, Analisis Junedi Lumban Gaol, Muryanto Amin \& Heri Kusmanto. Demokratisasi Dan Desentralisasi Partai Demokrasi Indonesia Perjuangan

di lihat dari indikator kualitas pelayanan yaitu kecepatan, ketepatan, keramahan, walaupun kenyamanan masih kurang baik di karenakan sarana yang belum memadai.

\section{Hambatan Pelayanan Bus Samsat Keliling UPPD Medan Selatan BPPDSU}

Sarana Yang Tidak Memadai. Yang sering di temukan adalah masyarakat yang mengeluh terhadap pelayanan Bus Samsat Keliling Simpang Pemda Kecamatan Medan Selayang mengenai kenyamanan lingkungan. Di karenakan sarana yang ada di Bus Samsat Keliling Simpang Pemda Kecamatan Medan Selayang masih kurang memuaskan. Seperti tempat yang panas dan tidak di sediakan tenda untuk wajib pajak. Dari hasil observasi peneliti, saat wajib pajak sedang mengantri tidak di sediakan tempat duduk untuk menunggu. Untuk mengantisipasi hal ini petugas harus menyiapkan tenda demi kenyamanan wajib pajak. Dan memberi kursi agar wajib pajak yang mengantri merasa nyaman. Menurut pihak Samsat sendiri, persiapan tersebut baru dalam tahap perencanaan dan akan segera di realisasikan demi kepentingan dan kelancaran pengguna layanan. Kenyamanan wajib pajak saat melakukan pembayaran pajak memang tidak senyaman pembayaran pajak di Samsat Induk. Yang fasilitasnya terpenuhi seperti adanya AC, tempat duduk yang nyaman, parkir yang luas. Hal tersebut di karenakan program Bus Samsat Keliling hanyalah bersifat sementara. Dan tujuan utama adanya program Bus Samsat Keliling ini di ciptakan hanya untuk orang-orang yang jauh dari Samsat Induk.

Ketidakdisiplinan Pegawai. Hambatan kedua yaitu tidak disiplinnya Petugas Bus Samsat Keliling di Simpang Pemda Kecamatan Medan Selayang. Hal ini terjadi karena Petugas Bus Samsat Keliling Simpang Pemda Kecamatan Medan Selayang masih melakukan pelanggaran disiplin kerja pelayanan dan kurangnya kesadaran bahwa kedisiplinan sangat penting dalam dunia kerja. Terdapat temuan yang dilakukan oleh Petugas Bus Samsat Keliling Simpang Pemda Kecamatan Medan Selayang terhadap hukum dan norma yang berlaku dalam bentuk sikap dan perilaku yang tidak patuh dan kurang tertib terhadap aturan yang telah ada seperti mentaati ketentuan jam kerja. Tuntutan masyarakat akan pelayanan yang semakin tinggi membutuhkan aparatur yang berdisiplin tinggi dalam menjalankan tugas. Namun kenyataannya tidak semua Petugas mentaati dan mematuhi peraturan perundang-undangan disiplin pegawai. Hal ini sesuai dengan Peraturan Pemerintah Nomor 53 Tahun 2010 tentang Disiplin Pegawai Negeri Sipil yang berbunyi masuk kerja dan menaati ketentuan jam kerja. Berdasarkan hasil observasi peneliti selama penelitian, Petugas Bus Samsat Keliling Simpang Pemda Kecamatan Medan Selayang melakukan pelanggaran disiplin terhadap waktu. Yaitu Petugas Bus Samsat Keliling Simpang Pemda Kecamatan Medan Selayang masuk dan pulang kantor tidak tepat waktu. Peneliti menyimpulkan Petugas Bus Samsat Keliling Simpang Pemda Kecamatan Medan Selayang perlu meningkatkan pelayanan terhadap masyarakat agar masyarakat tidak ada yang kecewa dengan pelayanan Bus Samsat Keliling. Peneliti melihat pelanggaran disiplin ringan yang di lakukan oleh Petugas Bus Samsat Keliling Simpang Pemda Kecamatan Medan Selayang adalah dengan tidak menaati jadwal pelayanan sesuai Keputusan Bersama TIM Pembina Samsat Provinsi Sumatera Utara Nomor: B/195/V/Kep/2021, 973/1070/BPPRDSU/2021 dan P/7/SP2021 tanggal 25 Mei 2021 Tentang Jadwal Pelayanan Samsat di Provinsi Sumatera Utara yang seharusnya pelayanan Bus Samsat Keliling di Simpang Pemda Kecamatan Medan Selayang di mulai pada jam 08.00 WIB sampai dengan jam 12.00 WIB namun kenyataannya Petugas Bus Samsat Keliling Simpang Pemda Kecamatan Medan Selayang mulai beraktivitas dari jam 09.20 WIB. Dan pulang pada jam di luar ketentuan yaitu jam 11.30 WIB.

Waktu Pelayanan Yang Terbatas. Masyarakat menginginkan waktu pengoperasian Bus Samsat Keliling Simpang Pemda Kecamatan Medan Selayang yang dapat di perpanjang tidak seperti di jam biasanya yang di mulai dari jam $09.20 \mathrm{~s} / \mathrm{d} 11.30$ WIB. Karena berdasarkan hasil wawancara selama penelitian, pelayanan selama 2 jam dirasa kurang untuk dapat memberikan kepuasan pelayanan kepada Wajib Pajak. Oleh karena itu diharapkan waktu pegoperasian Bus Samsat Keliling di Simpang Pemda Kecamatan Medan Selayang dapat di perpanjang.

\section{SIMPULAN}


Berdasarkan hasil penelitian yang menggunakan 4 indikator dari Tjiptono (2002) mengenai kualitas pelayanan pada program Bus Samsat Keliling Simpang Pemda Kecamatan Medan Selayang, maka hasil yang di dapat pada indikator kualitas pelayanan yaitu kecepatan, ketepatan, keramahan sudah baik atau berkualitas. Namun pada indikator kenyamanan masih kurang baik atau kurang memadai di karenakan sarana yang masih terbatas. Hambatan pelayanan Bus Samsat Keliling Simpang Pemda Kecamatan Medan Selayang, adalah masyarakat yang mengeluh terhadap fasilitas. Di karenakan sarana yang ada di Bus Samsat Keliling Simpang Pemda Kecamatan Medan Selayang masih kurang memuaskan. Seperti tempat yang panas dan tidak di sediakan tenda untuk wajib pajak. Tempat parkir yang terbatas, tidak ada kursi bagi wajib pajak, tidak adanya nomor urut antrian, sehingga wajib pajak seringkali merasa kepanasan dan kehujanan di saat cuaca tidak mendukung. Hambatan kedua yaitu tidak disiplinnya Petugas Bus Samsat Keliling di Simpang Pemda Kecamatan Medan Selayang. Hal ini terjadi karena Petugas Bus Samsat Keliling Simpang Pemda Kecamatan Medan Selayang masih melakukan pelanggaran disiplin kerja. Yaitu Petugas Bus Samsat Keliling Simpang Pemda Kecamatan Medan Selayang masuk dan pulang kantor tidak tepat waktu. Hambatan ketiga masyarakat menginginkan waktu pengoperasian Bus Samsat Keliling Simpang Pemda Kecamatan Medan Selayang dapat di perpanjang. Berdasarkan hasil penelitian, pelayanan selama 2 jam dirasa kurang untuk dapat memberikan kepuasan pelayanan kepada Wajib Pajak.

\section{DAFTAR PUSTAKA}

Aman. (2007). Metode Penelitian Kualitatif. Yogyakarta: UNY Press.

Arikunto, S. (2013). Prosedur Penelitian: Suatu Pendekatan Praktik. Jakarta: Rineka Cipta.

Hendrawan, A.I. Kusmanto, H. \& Warjio. (2018). Pengaruh Kualitas Pelayanan terhadap Kepuasan Publik di Badan Pengelolaan Pajak dan Retribusi Daerah Kota Medan. Jurnal Administrasi Publik : Public Administration Journal. 8 (1): 65-84.

Khainuddin, K., Kusmanto, H., \& Isnaini, I. (2019). Analisis Kualitas Pelayanan Publik Rawat Inap Pada Badan Layanan Umum Rumah Sakit Umum Daerah Kota Subulussalam.
Strukturasi: Jurnal Ilmiah Magister Administrasi Publik, 1(1), 22-31

Minallah, F., Lubis, L., \& Achmad, N. (2021). Kualitas Pelayanan Pajak Kendaraan Bermotor Pada Kantor Sistem Administrasi Manunggal Satu Atap Putri Hijau Medan Utara. PERSPEKTIF, 10(2),

527-542. doi:https://doi.org/10.31289/perspektif.v1 $0 \mathrm{i} 2.4765$

Narita, A.A.S, Warjio, Agus S, (2016), Analisis Kualitas Pelayanan Pada Kantor Dinas Pendapatan Provinsi Sumatera Utara UPT Medan Selatan, Jurnal Administrasi Publik, 6 (2): 87-96.

Ningrum, D., Fitriani, N., \& Sudrajat, A. (2019). Kualitas Pelayanan Mobil Unit Penerangan pada Dinas Pengendalian Penduduk dan Keluarga Berencana Kabupaten Sumedang. Jurnal Administrasi Publik : Public Administration Journal, 9(2), 113-118. doi:https://doi.org/10.31289/jap.v9i2.2414

Panjaitan, E. Dewi, R. \& Angelia, N. (2019). Peranan Pemerintah Desa dalam Meningkatkan Kualitas Pelayanan Administrasi kepada Masyarakat. PERSPEKTIF, 8 (1): 32-38.

Prasetio, E., Isnaini, I., \& Adam, A. (2021). Analisis Kualitas Pelayanan Perizinan melalui Online Single Submission pada Dinas Penanaman Modal Dan Pelayanan Perizinan Terpadu Satu Pintu Kota Binjai. PERSPEKTIF, 10(2), 710727.

doi:https://doi.org/10.31289/perspektif.v1 $0 \mathrm{i} 2.5176$

Sampara, L. (2000). Manajemen Kualitas Pelayanan. Jakarta: STIA LAN Press.

Saputra, U., Larasati, E., Yuniningsih, T., \& Astuti, R. (2021). Perkembangan Tren Penelitian Kualitas Pelayanan Di Indonesia. Journal of Education, Humaniora and Social Sciences (JEHSS), 4(2), 728-756. doi:https://doi.org/10.34007/jehss.v4i2.734

Silalahi. A.F.L, Syafruddin, R. \& Beby, M.B. (2019). Kualitas Pelayanan Publik dalam Pemberian Izin Mendirikan Bangunan di Badan Pelayanan Perizinan Terpadu. PERSPEKTIF, 8 (1): 8-14

Sugiyono. (2013). Metode Penelitian Pendidikan. Bandung: Alfabeta.

Sunarno. (2010). Dasar-Dasar Kebijakan Publik: Kajian Proses \& Analisis Kebijakan. Yogyakarta: UNY.

Suyanto, B. (2005). Metode Penelitian Sosial: Bergabai Alternatif Pendekatan. Jakarta: Prenada Media.

Tjiptono, F. (2005). Prinsip-Prinsip Quality Service. Yogyakarta: Andi Offset.

Undang-Undang Nomor 25 Tahun 2009 tentang Pelayanan Publik. 
Hubalillah, Badaruddin \& Heri Kusmanto, Analisis Junedi Lumban Gaol, Muryanto Amin \& Heri Kusmanto. Demokratisasi Dan Desentralisasi Partai Demokrasi Indonesia Perjuangan

Peraturan Pemerintah Nomor 18 Tahun 2016 tentang Perangkat Daerah.

Peraturan Pemerintah Nomor 31 Tahun 2004 tentang Tarif atas Jenis PNBP.

SK Menteri Pertahanan Keamanan/Panglima Angkatan Bersenjata, Menteri Keuangan, dan Menteri Dalam Negeri dengan Nomor: Pol. KEP/13/XII/76.KEP.1693/MK/IV/12/1976 dan Nomor 311 Tahun 1976 tentang Peningkatan Kerjasama Antara Pemerintah Daerah Tingkat I (Provinsi), Komando Kepolisian dan Aparat Departemen Keuangan
Dalam Rangka Peningkatan Pelayanan Kepada Masyarakat Serta Peningkatan Pendapatan Daerah.

Laporan Peraturan Gubernur Sumatera Utara Nomor 22 Tahun 2017 Tanggal 3 Mei 2017, tentang Struktur Organisasi UPPD Medan Selatan BPPRDSU.

Peraturan Pemerintah Nomor 53 Tahun 2010 tentang Disiplin Pegawai Negeri Sipil. 